\title{
CHRISTIANITY AND AWKA SOCIO-RELIGIO-CULTURAL IDENTITY CRISIS: AREAS OF CONFLICT
}

\author{
Patrick Enoch Nmah \\ http://dx.doi.org/10.4314/og.v12i s1.5
}

\begin{abstract}
The problem of religious and cultural conflict still baffles many scholars of religion, sociology and anthropology. This article was designed to investigate and $\mathrm{x}$-ray critically the religious values, beliefs and practices among the Awka people of Nigeria that were involved in the socio-religious conflict. Findings showed that the issues involved in the conflict were the Imo Awka festival, burial rites (ikponye aja n'ili-dust-to-dust rite), and okuko onye uwa (hen sacrificed to family deity to validate a marriage bond). It was recommended among others that the church and Awka people should in the way of resolving conflict situation use the least expensive method without much acrimony. The main aim of this research was to shed some light on the consequences of this socio-religio-cultural conflict. The method applied in the research work was historiophenomenological approach with the review of related literature.
\end{abstract}

\section{Introduction}

This article aims at articulating the socio-religious and cultural conflicts associated with Imoka festival, burial rites and okukoonyeuwa (hen sacrificed to idol) in Awka. There is the need to give accurate information that will correct the misinterpretation and misinformation going round in the Awka in respect of the three issues raised above. The significance of the research is that it will be useful for academic knowledge and practical aims. The method applied is historio-phenomenological approach. Related extant materials were used in the course of the research.In summary, what is being said is that every community has its own religion. The relationship between God and human communities has taken different forms. Each particular religion has a particular character, because of the people who practice it. The aim of this paper is to create awareness of true missional Christians who have reflected deeply about their own theological engagement with people of different faith such as in Awka, and who are therefore able to 
Nmah: Christianity and Awka Socio-Religio-Cultural Identity Crisis...

champion their ideas intelligibly and spiritually in writing, in preaching, in character and learning. In the course of this research work, identity and value shall be used interchangeably.

\section{Conceptual Framework}

To Shaver, and Strong (1976), values are "standards and principles for judging worth. They are the criteria by which we judge 'things' to be good, worth, while, desirable; or on the other hand, bad, worthless, despicable; or of course, somewhere in-between these extremes. We may apply our values consciously. Or they may function unconsciously, as part of the influence of our frames of reference, without our being aware of the standards implied by our decisions"(p.15). There are three important elements in the above definition namely first, that values are concepts, not feelings; second, that we may not be conscious or explicitly aware of the values we hold; third, that values are dimensional rather than absolute categories.

Rokeach (1973) remarks that a value is a belief and like all beliefs, values have cognitive, affective, and behavioural components. Shaver and Strong (1976) distinguished three important categories of values such as aesthetic values (judging beauty), instrumental values (they are standards set to achieve other standards), moral values (the standards, the principles, by which we judge whether aims or actions are proper). Value is a modern term used to indicate what traditionally has gone by the name of 'good' or "the good" (Macquarrie, 1981).

The English social scientist, Taylor (1871) has defined culture as "that complex whole which includes knowledge belief, art, moral, law, custom, and any other capabilities and habits acquired by man as a member of society" (p. 21). This view suggests that culture includes tools, weapons, fire, agriculture, animal domestication, metallurgy, writing, the steam engine, glasses, airplanes, computers, penicillin, nuclear power, rock-and-roll, video games, designer jeans, religion, political systems, subsistence patterns, science, sports, and social organizations. In Taylor's view, culture includes all aspects of human activity from the fine arts to popular entertainment, from everyday behaviour to the development of sophisticated technology. It contains the plans, rules, techniques, designs, recipes, and policies for living. This nineteenth century 
definition of culture has become a terminology that would not be acceptable to modern anthropologists. For example, it relies on the word "man" to refer to what we presently would refer to as humanity. Presently, most anthropologists would accept a broad conception of culture as a shared way of life that includes values, beliefs, and norms transmitted within a particular society from generation to generation. This definition does not make a distinction between culture and society, but the term society.

The sociologist, Fichter (1957) has also concisely defined culture as, "The total configuration of institutions that the people in society share in common" (p. 270). Culture may be defined as the fabric of ideas, beliefs, skills, tools, aesthetic objects, methods of thinking, of eating and of talking, the music he plays, celebrating and festivals, modes of communication and transportation (Iwe, -).

Culture is a fundamental concept within the discipline of anthropology (Scupin, 2000). In some cases, many people use the word culture to refer to "high culture" such as Shakespeare's works, Beethoven's symphonies, Michelangelo's sculptures, government cooking, imported wines, and so on. Culture is fundamental to human existence and human civilization. It is dynamic and it embodies the totality of a people's response to the challenges of life and living (Nmah, 2012). It offers meaning, purpose, and values to the socio-economic, religious, political and aesthetic ethos of society (Obafemi, 2011). It is the main factor of determining one's identity, religion and relevance in community. According to Evwierhoma (2007), culture persuades everything a human being does, plans to do and not do. It is mainly earned or acquired through instruction, interaction and other means of cultural transmission.

In most countries where modern anthropologists conduct ethnographic research, the societies are extremely complex and consist of distinctive groups that maintain different cultural traditions. Thus, this simple distinction between society and cultural issues is too artificial for modern anthropologists. Some anthropologists have adopted the hybrid, term socio-cultural system, a combination of the terms society (or social) and culture-to refer to what used to be called "society" or "culture" (Scupin, 2000, p.7).

When anthropologists refer to the concept of culture, they are emphasizing a non biological property. Culture is not hereditary through our genes in the way we inherit our physical characteristics, 
such as eye colour or body build-indeed, we obtain our culture through the process of what is called enculturation. Enculturation is the process of social interaction through which people learn and acquire their culture. Humans acquire their culture both consciously through formal learning and unconsciously through informal social interaction (Scupin, 2000). Sagarin (1978) defines culture as the complex whole that consists of all the ways people think and do everything they were as members of society.

Another form of learning important to enculturation is called social learning, which occurs when one person observes another person or other people responding to a circumstance and then adds that response to their own collection of behaviours. Humans learn by observing classmates, teachers, parents, friends, and the media. Obviously, the form of learning that is most important for culture is known as symbolic learning. Symbolic learning is based on our linguistic capacity and ability to use and understand symbols, arbitrary meaningful units, or models that humans use to represent reality. They are the conceptual devices that we use to communicate abstract ideas to each other. We communicate these symbols with each other through our language. Humans learn most of their behaviours and concepts through symbolic learning. Symbolic learning has almost infinite possibilities in terms of absorbing and using information in creative ways. Most of our learning as humans is based on this symbolic learning process.

According to Scupin (2000), the human capacity for culture is based on our linguistic and cognitive ability to symbolize. Culture is transmitted from generation to generation through symbolic learning and language. Culture is the historical accumulation of symbolic knowledge that is shared by a society. This symbolic knowledge is transmitted through learning and it can change rapidly from parents to children and from one generation to the next.

When discussing the concept of culture, anthropologists have tried to isolate the key elements that constitute culture. Two of the most basic components are material and non-material culture. Material culture comprises the physical products of human society (ranging from jewelry, houses, weapons, clothing styles, to temples or churches), while non-material culture refers to the intangible products of human society (values, beliefs, and norms). The term values refer to the explicit standards by which members of a society 
defined what is good or bad, holy or unholy, beautiful or ugly. They are well-known assumptions that are widely shared within the society. Values are a central aspect of the culture of a society and they are important because they influence the behaviour of the members of a society. Values, beliefs, norms, and worldviews are terms used by many anthropologists when referring to aspects of culture. Thus, enculturation is an imprecise process. People may internalize the general program for behaviour-a series of ideal values, beliefs, worldviews, norms, rules, and cultural guidelines for action-but how these general principles apply in any specific set of concrete circumstances is difficult of impossible to specify.

Cultural patterns are passed on from one generation to another through time by means of education. By education method, we do not here mean only that sort of learning which takes place in school rooms namely formal school learning. All traditional societies had methods of education long before Europeans brought Western formal education to them. Some of it was formal, that is fixed and laid down in established patterns, as in the bush school initiation rites of certain societies. Other aspects of it were informal, that is, arising out of day-to-day situations, not predetermined. But whether it was formal or informal, the function of education was to pass on the accumulated wisdom of the society to a new generation. Every society has, in the course of its history, found ways of dealing with problems, and passes them on to its young. If, as an African, you tell your child that the unity of the village is more important than anything else, more important even than his own individual pride, you are educating him in the accepted ways of your culture. There is thus no single pattern of behaviour which can be called culture. Every society has its own culture.

The patterns of behaviour comprising culture can be analyzed in terms of four categories: values, beliefs, symbols and norms. To Obiajulu (2003), culture is the complex pattern of living that directs human social life. The things each generation must learn and to which they eventually may add. Cultures interpret on surroundings for us and give them meaning and allow us to express ourselves (Chirot, 1994). Language, religion, science, and arts, notion of right and wrong explanations of the meaning of life-these are all part of the cultural systems of a society. 
Culture in the words of Shark (1996) means, "The sum total of human creations - intellectual, technical, artistic, physical and moral" (p.43). Every society has its own culture. The word culture is used to mean those ways of behaviour which are customary in any particular society (Krass, 1982). Some of these customs are economic, political, judicial, religious or technological. Each society has its own unique culture or set of customs. According to Nmah (2004), culture involves the sum of all that have spontaneously arisen for the advancement of material life and as an expression of spiritual and moral life - all social intercourse, technologies, arts, literature and science. In other words, it is the work of man's minds and hands. The definition of culture given by Taylor, Fichter, and Scupin shall form our working definition.

According to Nmah (2011), the definitions and uses of the term identity are legion, especially among religious scholars and social psychologists. To an extent, the term identity refers to who somebody is or what something is. It could be regarded as selfrealization or self-awareness as awareness could be defined as consciousness of one's existence and characteristic, usually in relationship to other people or objects. Consequently, self-identity has to do with self-esteem and recognition by others.

Identity has both biographical and spatial dimensions in that it deals with either what a person or thing are essentially, his or its place in a universe of interactions and relationships, a universe that is potentially chaotic, because of the absence of reliable reference points, and his/its role in that universe. The spatial dimension of identity has to do with the question of boundaries-sociographic and psychological. We know that much of the trouble in the world today can be attributed to the problem of people crossing other people's boundaries either intentionally or inadvertently. Identity helps to demarcate these personal and collective boundaries in order to ensure interpersonal harmony and peaceful co-existence. The Awka identity crisis with the church deals with religious, cultural and ethnic identity. In other words, we hear of a definite longing to give religion in Africa a distinctive African identity or echoes of a yearning for what Hackett (2012) calls, in the Nigerian context, "religious self-determination.

Nmah citing Emile Durkheim defined religion as a unified system of beliefs and practices, which are relative to sacred things, 
things set apart or forbidden-beliefs and practices that unite one single moral community called a church and all those who adhere to them. Karl Marx defined religion as the opium of the people. J. Milton Yinger defines also religion as "a system of beliefs and practices by means of which a group of people struggle with these ultimate problems of human life. The definitions given to religion by Emile Durkheim and J. Milton Yinger will be applicable to this research work.

From this definition of religion, we turn now to the task of defining conflict. Conflict is a process that begins when one person sees that another person has damaged or about to damage something that the other person cares about (Nmah, 2008 and 2009). This definition shall be relevant to this research work. As people with different backgrounds, points of view, values, needs, religions and personalities interact, a variety of conflicts often develop. There are about four types of conflicts namely functional conflicts, dysfunctional conflicts, a person versus person conflict, and person versus group. Dysfunctional conflicts are destructive conflicts characterized by cold wars. A person versus person conflict involves two persons who are odds over personality differences. Functional conflicts are constructive conflicts.

\section{Awka People: A brief Ethnography}

To Okafor (1992), there is a mystery with regard to the origin of the first $O \mathrm{Ka}$ (Awka) people, that nuclear group around which other people attached themselves to form Oka town. These first $O k a$ people were known as Ifiteana. To them others came and joined them and they all fused together to become one whole-the $O \mathrm{ka}$ people of today. These Ifiteana people were living in $\mathrm{Oka}$ under the names of Urueri, Amaenyiana and Okpo respectively. Who they were, where they came from (if they came from somewhere), who their own ancestors were, are not known. Oka people simply said of themselves that they were Ifiteana stock.

Okafor (1992) maintained that Awka people claimed to be the most ancient nation in Igboland and that no other nation surpassed them in antiquity. Thus other people have history or stories of where they came from but Awka have none. They believed that other Igbo communities took the names of their gods and days of their week such as Eke, Oye, Afo and Nkwo from them. The name 
Oka is derived from Okika-na-Ube shortened to Okanube. Okika-naUbe is the god of war ad hunting and the Ifiteana people the progenitors of Awka worship Okika-na-Ube; so they were called Umu-Okanube or Umu-Oka hence their town became Oka. The name Oka was changed to Awka in 1908 by a British colonial secretary, Mr. F.S. James.

Furthermore, this Ifiteana community lives together at the present Nkwelle later they separated. Urueri remained at Nkwelle with the original Nkwelle people namely Achallaoji, Umunamoke, Agbana and Umudiaba who came and joined them and they become one village. But it is unfortunate that the original Urueri later decreased in number to the extent that they joined Achallaoji family. Amaenyiana on the other hand were later split into two; the main Amaenyiana and Ndu group. They all live in OkpunoOchu the present old Enugu and ring road junction. The main Amaenyiana group does not live long because they killed their brother and were asked to leave the town. Ndu group later moved to the present Umuayom and formed Umuokpandu family. This made them to take over the headship from Urueri. The Okpo people settled near Nwannu stream. They were the founders of the three villages, Amachalla, Amudo and Umuzocha popularly known as Amachallana-ato meaning the three Amachalla villages.

Other people that came to settle in Awka are Umudioka and Agulu. Umudioka came from a town in Idemili known as Umudioka -Akpom. They were popularly known as Diokas. The Diokas usually came to Awka to do business. Later one of them known as Ichide decided to settle at Awka. He later got married to Nwanyanwu. Nwanyanwu is from Amikwo village. She bore four sons. Ichide having seen that he has settled in Awka called his brother Udeke. They both settled together and were the founders of the five families of Umudioka Village popularly known as Umudioka-Obu-nese.

Another theory of $\mathrm{Oka}$ origin has it that the founding father was Nneoshi (Kanu, 1996). He wandered from one place to another probably in search of a better place to farm and hunt and later found himself at the present Ugwuoba in Enugu State. He settled there and has two sons Ugwuoba and Oka. When Nneoshi died, Ugwuoba his first son occupied his father's obi and lived in the family house as the tradition demanded and the name of the place became Ugwuoba. 
Oka who is the second son moved out of the compound and settled at Amaenyi meaning the abode of elephants in the present Awka. His families were the founders of the two major sections in Awka namely Ifite and Ezi. Ifite section were the original habitation of Ifiteana while Ezi were the outskirts that is why Ifite section always take the first share and Ezi the second in sharing of things in Awka. Udoye and Ofoegbu (2011) said that, "Awka comprises thirty three (33) villages grouped into two Ezi and Ifite sections and each section is divided into three and four quarters respectively." (p. 85). The two sections and their respective quarters are Ezi with Amikwo, Agulu and Ezioka quarters. The Ifite section has the following Ayom-naOkpala, Amachalla, Nkwelle and Ifite-Oka quarters. In sharing things quarter by quarter Ayom-na-Okpala takes first share, because of a part of Amaenyi-ana family known as Umuokpandu family that are living there who became the head after the disappearance of Urueri while Nkwelle especially the Achallaoji takes the second share, because of the remaining part of Urueri that joined them. The thirty three villages in Awka in order of taking shares according to Okafor (1992) are: Umuayom, Umunnoke, Umuoramma, Umuokpu, Achallaoji, Umunamoke, Umudioka, Agbana, Amachalla, Amudo, Umuzocha, Ezinato-Ifite, Enu-ifite, Agbana-itife, Omuku, Umueri, Umukwa, Umuogwai, Umuogbunu 1, Umuogbunu 2, Umudioka, Umudiana, Okpaeri, Igweogige, Isiagu, Obunagu, Umuogbu, Umubele, Umuanaga, Umuike, Umujagwo, Umuenechi and Umuoruka" (p.42).

\section{Occupation}

Awka is a rich town blessed with economic trees, water and other natural resources. They are not very good in farm work. They substitute agricultural practices with crafts work. Okafor (1992) asserts that Oka people before the advent of British people in 1905 were great people, resourceful, inventive and courageous. They specialized in iron, copper, brass, and bronze work. Afigbo (1981) said that "after the Awka blacksmith had finished his assignment, Eri rewarded him with an ofo which conferred on him special claims to the smith profession" (p. 41). This depicts that Awka people are professional blacksmiths, since ofo is a symbol of authority. They specialized in producing farm implements, hunting spears, weapons of offence and defence like guns, knives. They manufacture also 
musical instruments like ogene (gong). Hence Awka people were known for egwuogenethe metal gong music. They use it to make money and to entertain people during Imoka festival, marriage ceremony, title taking and funeral rites and so on.

Awka people substitute agriculture with crafts work, but that does not mean that they do not farm at all. Hence they practice subsistence system of farming. They cultivate crops like maize, cassava, and vegetables. Some of their women use the cassava to produce garri that is why there are cassava grinding machine centers in Awka urban. Their major markets are Eke Awka and NkwoAmaenyi markets where people from Awka and nearby communities buy and sell their farm products.

Christianity, civilization through western education, commerce cum Awka new status as the capital city of Anambra state and headquarters of Awka South L.G.A. made Awka people to assume a new form of occupation. Apart from Paul University and Central School Awka, which were among the oldest schools in Awka, there are many public and private schools in Awka nowadays. The establishment of primary and secondary schools cum universities in Awka gave the people opportunity to attend school. Today most of them are graduates and this offered them white collar jobs. Thus some of them are medical doctors, teachers, soldiers, policemen, lawyers, African traditional and Christian religious leaders, and bankers in both public and private establishments in and outside Awka.

\section{Awka Religion and Culture}

The most common religion in Awka is the Igbo traditional religion (at times known as African traditional religion). In respect of cultural practices or festivals, the most popular cultural festival in Awka is the Imoka festival. Okafor (1992) said the Akpoto native doctors from Idoma were invited by Awka people to prepare a medicine to appease the spirit of Nomeh who was the most beautiful girl in Awka then and was said to have been murdered at Umuezeukwu war with Awka people. Nomeh was buried in what is now the shrine of Imoka. The name of the medicine Akpoto native doctors made for them is Akwali-oda-omumualso known as AkwaliUmuoka or Imoka. Okafor believed that the medicine was buried at the spot Nomeh was buried and when the medicine became powerful Awka people started 
worshipping it as a god and celebrate its festival once a year. Thus Imoka or egwuImoka became an annual festival in Awka that takes place mostly in the month of May.

During this festival, Awka people both home and abroad members are expected to participate in the festival. Masquerades from various villages in Awka are expected to assemble at Imoka shrine at NkwoAmaenyi market. The women celebrate their own a day before the men's day. On the women's day, masquerades are not allowed to perform that day while on the men's day which is the actual Imoka day masquerades are allowed to perform. It is also pertinent to point out that Imoka festival takes place four days after the visit to Umuokpu shrine. One of the sacred or totemic animals in Awka is the enweImoka (black money) which is venerated and cannot be killed by the people. This is because of the people's belief that the black monkeys are the Imoka children and that Imoka used them to inform Awka people that war is approaching Awka if there is a threat of such.

\section{The Advent of Christianity in Awka}

Christianity came to Awka in 1899 and 1903. Their first visit in 1899 was on one of their major market days and their arrival attracted a crowd. Okafor (1992) said that AvoAgulu was in full swing. Men and women, but mostly women were bustling about pricing and re-pricing commodities offered for sale. Suddenly there was a more than usual excitement from Umuenechiend of the market so people gathered to know what was happening and they saw an Awka man from Umuokpu leading the missionaries; a white woman and two white men who were church missionary society missionaries. The people were excited and those that followed them reported that they stopped at the house of OwoUkaozo in Umuanaga village. Okafor said that the missionaries were of the Anglican Communion. They preached the gospel to the crowd and promised that they will come again. The missionaries visited again in 1903 and the people gave them a land to build a church at the place known as Ajo-ofia (evil forest) by Agulu quarters. Later another land was given to them near Udo shrine at Iyiokpu quarters where they built both school and church known as St. Faith School and St. Faith Church respectively. Today there are many churches in Awka such as the Roman Catholic Church, Methodist Church Nigeria, and 
Presbyterian Church of Nigeria. The Baptist Church, Evangelical Church of Winning All, Deeper Life Bible Church, Mountain of Fire and Miracles Ministries, The Redeemed Christian Church, The Assemblies of God Church, Grace of God Mission and so on.

According to Idowu (1973), when the missionaries came to Nigeria to teach and preach, they found ready to their hands communities of people who were educable in every way. Apart from preaching the gospel, they taught their converts or the adherents of the new faith to read and write, employing, of course, the only method known to them-that of western education (English system mainly). By a certain miscarriage of purpose, however, their effort succeeded not only in enlightening, but also in enslaving the mind, inasmuch as it inculcated that the only way to human dignity and full-grown personality was to be in everything like Europeans and to despise their own culture. It was in this way that Christianity arrived in Awka dressed up in European garb. It was immediately associated with civilization in the sense of being well dressed in European fashion, dexterity in European etiquette and manners, and proficiency (or dabbling) in the use of English language with a corresponding disdain for their own culture, a disdain which crystallized into inability to use their own language properly. It must be said here that if at the beginning, any one had enough vision to suggest that while accepting Christianity, Awka people did not need to throw away what was good and valuable in their own culture, such a person would have been accused of rank 'heathenism' by the European religious educators whose set purpose was to exterminate as of the devil anything that had no meaning for them; such a person would also probably have been stoned by the Awka natives in whom inferiority complex was them finding a soothing compensation in the adoption of what appeared to them to be a fashionable and more acceptable way of life. Thus, today, we find especially in Catholic, Anglican and like churches that in spite of the political independence of Nigeria, the way things are done in Europe and America still forms the norm and standard by which the life of the Church is ordered. 


\section{Christianity and Awka Socio-Religio-Cultural Identity Crisis: Area of Conflict}

In exploring the above one can see that Awka people are both Christians and largely ardent members of African traditional religion. The advent of Christianity did not make them to disregard their traditional religion; although there are some areas of conflict between Christianity and the people's religion and culture. The prevalent conflict in the town now comprises religion, Imokafestival, marriage and burial rites. The later, ikponyeaja (to shovel sand) into the grave by a widow is also a serious conflict in Awka. Ofodile (2013) said that:

There are instances of priests refusing to conduct funeral services for deceased members just because the widow may not be allowed by villagers to perform dust to dust task since our tradition prefers a male child of the deceased to execute exactly the same role (p.1).

This is a serious problem between the church and the people especially members of the Roman Catholic Church. The people insist that the church must allow them bury their love ones in accordance with their tradition. They maintained that if the Church must allow widows to do shovel sand-ikponyeaja, they should go and get a cemetery for their church members, because they will not be cowed to allow the widows to perform burial rites that are contrary to their culture, tradition and religion in their community. The case in point is the burial rite of dust-to-dust controversy between the Catholic Church and Umudioka youths on $3^{\text {rd }}$ May, 2013 in which the burial requiem mass was disrupted. The military men and police that were invited to maintain peace and order could not perform, because of the influence of an ex-army General and a serving police commissioner who are from Umudioka Awka and are on the side of the Umudioka village youths (Okeke, 2015). The youths smashed the altar set for mass and broke the candle globes, the crucifix and other materials for the burial mass. All these sacred vessels they buried in the grave being dug. In order to avoid bloodshed and taking the laws into their hands, the corpse of the 
deceased, which has already arrived in the compound, was redeposited at Regina Caeli mortuary, Awka. From the order given by the Bishop, Most Rev Dr P.C. Ezeokafor, the burial rite was put off till further notice. The family and the church encountered many losses, because of the disruption.

In respect of marriage, during separation or divorce, children are given some certain rights in their maternal family homes especially where their biological fathers did not perform the traditional rite called the okukuonyeuwa rite. But where the marriage contract is valid through the okukuonyeuwa rite, any child borne to the woman during separation or before the dissolution of the marriage bond belongs to her husband. The okukuonyeuwa marriage rite is another area of conflict between Christians and the natives. The rite is regarded as idolatry by Christians. In Awka, marriage without bride price, okukuonyeuwa rite and blessing from their parents will definitely build a house of conflicts which shall eventually lead to separation. Failure on the side of the groom to perform these rites especially the okukuonyeuwa rite shall result in the man losing the right to own his biological children. It is a practice where a fowl is sacrificed to the family deity before a woman leaves her maiden home. The woman and her husband are then made to consume the fowl sacrificed with some form of incantations. This rite is considered by Awka people as the wedding proper and without it; there is no valid marriage (Kanu, 1996, p. 35). Okukuonyeuwa rite is a ceremonial meal that seals the marriage contract between the two families involved in the marriage. Hence the fowl soup and pounded yam must be served to the two families. Okafor (1992) said that "after that meal prepared with the things brought by the husband's people, the girl becomes their wife" (p. 23). Thusokukuonyeuwa rite is the only thing that makes marriage contract valid in Awka. That is why any man (bridegroom) who paid only the bride price will be deprived of the children during separation or at death because he did not complete the marriage rite. To Awka people, okukuonyeuwa rite seals the marriage and enhances the marriage bond between the two families.

Firstly, the fact that the Christianity that came to Africa was in general fully steeped in western personnel, western culture, western philosophy, western theology and western psychology and cultural values such as monogamy, institutional celibacy, flowing 
garments reminiscent of the Roman toga or of Medieval Europe, western patterns of prayer and incantations, rituals and ceremonials, and western names and concept of authority. All these have still being swallowed uncritically by the Africans in the name of Christianity and to the detriment or neglect of their own culture.

Secondly, the failure of the Christian missionaries to appreciate effectively the positive elements of our culture and religion is to say the least.

Thirdly is the fact that the Christian missionaries in their invincible if inculpable anthropological ignorance of the Africans, conceived or seemed to have conceived their mission as that of imparting not only the Christian religion, but also culture and civilization-and the western civilization precisely.

Fourthly, exclusivism in Christian tradition holds that there is only one true, saving religion, that is Christianity. That branch of theology which is in opposition to the non-Christian religions shows the Christian religion to be the way, the truth and the life which seeks to dispossess the non-Christian religions and to plant in their stead in the soil of heathen national life the evangelistic faith and the Christian life (Jn. 14:6; Hick and Knitter, 1987).

However, fortunately, the voice of those demanding or requesting a thorough-going Africanization of Christianity or incarnational theology in African is becoming audible and appreciably effective. It is this "Africanization", "accommodation", and "Christianization or rather incarnational theology in Africa that was not sufficiently provided for by the Western founders of Christianity in Africa owing to their cultural limitations and the social constraints of our communities (Iwe, -, Nmah\&Udezo, 2015, Ikenga-Metuh, 1996). The basic functions of culture include coping with certain universal problems and events, establishing an orderly way of life, and for satisfying the biological needs of its members. It exists in order to systematize the satisfaction of the social needs of people (Mussen, 1963 and Fichter, 1957).

\section{Antiseptic Panacea to Christianity and Awka People's Religious and Cultural Identity Crisis}

As a way to ameliorate the situation, aggressive evangelism should be carried out by pious ecclesiastical leaders, priests, evangelists and catechists. Synergies on the side of the church are needed in this 
respect. It was observed in the course of this research, that the early missionaries as a result of their non-chalantbehaviour regarding these practices, their intra and inter rivalry attitude among the different denominations who were much interested in areas of influence rather than transforming the mental and spiritual lives of their converts to be conformed to Christ life were responsible for this conflict.

This spiritual lackadaisical attitude of the missionaries and majority of the contemporary Christians is also responsible for the spiritual lukewarm or the deadly lethargic behaviour of the "Awka proselytes" and "non-converts". Disgusted with the church, the converts have to resort firmly to their religious beliefs and practices cum Christianity. Consequently Christianity to them is a persona non grata religion to Awka. The early Christians made some mistakes by not condemning such practices out right abinitio; however, the Christians can engage the natives through religious dialogue, seminars, conferences, workshops, symposia and revivals.

There is also the need for the church to intensify teachings on the issues involved, but not necessarily during the seasons of Imoka, Okukuonyeuwa rite and ikponyeaja, but the teachings should be done season and out of season. The people of Awka should be made to have sober reflection on the teaching of St. Paul on idolatry and Christian faith in 1 Corinthians 10:1-22 especially verses 14-22. Other passages that may be considered relevant include Judges 6:25; 1 Kings 18:25, 19:18; 2 Kings 10:25; Jeremiah 19:5; Romans 14: 4; and 1 Corinthians 11:27.

The Awka people should be magnanimous enough to reform their religious beliefs and practices like reformed Ogboni fraternity, because culture is man-made and therefore it is not static, but rather dynamic. The idea of flogging motorists, pedestrians, cyclists and extorting money from the people is wrong in its entirety. It is stealing by violence. Blocking the major roads within the town during the Imoka festivity is not the best option. The festivity should be entertaining, educative and informative in nature.

As in Corinthians (1 Cor. 10:14-22), when sacrifice is offered in Awka, part of the meat is given back to the worshippers to hold a feast just as during the period of Imoka and okukuonyeuwa rites. At such a feast it was always held that the god himself was a guest. More, it is often held that, after the meat has been sacrificed, the god 
himself was in it and that at the banquet he entered into the very bodies and spirits of those who ate. In other words a sacrificial meal formed a real communion between the god and his worshippers. The person who sacrificed was in a real sense a sharer with the altar; he has a mystic communion with the god (Barclay, 1982). Paul believed in these sacrifices rendered to demons; he called them "principalities and power." His point of view was this-an idol was nothing and stood for nothing; but the whole business of idol worship was the work of the demons; through it they seduced men from God. When they were worshipping idols, men thought they were worshipping gods; in fact they were being deluded by these malignant demons. Idol worship brought a man into contact, not with God, but with demons; and anything to do with it had the demonic taint on it. Meat offered to idols was nothing, but the fact remained it had served the purposes of demons and was therefore a polluted thing.

Out of this ancient set of beliefs and practices comes one permanent principle a man who has sat at the table of Jesus Christ cannot go on to sit at the table which is the instrument of demons. If a man has handled the body and blood of Christ there are things he cannot touch. The man who has handled the sacred things of Christ cannot soil his hands with mean and unworthy things.

\section{Conclusion and Recommendations}

Religion and culture, they are known in history as interwoven values among religious groups, living and developing organizations that have been on the move from the past into the present and into the future. They contain among other things self-control, kinship, good neighbourliness, benevolence, belief and practice (Iwe, 1991). In spite of these noble merits, one still finds that religion in Nigeria especially in Awka is ambivalent. On one hand, it promotes group solidarity and on the other, it fosters ethnic socio-religious and cultural fanaticism, fundamentalism, and intolerance. This paper has examined the Christianity and Awka socio-religio-cultural identity crisis: area of conflict. The conflict centers on ethnic identity. In summary, the main crux of the research in this paper is that the church and Awka people are either competing for superiority complex or inferiority complex that revolves around church practices and socio-religious and cultural identity. I therefore recommend the following as a panacea to the conflict. 
From the research work, I was able to discover those Imoka festival and okukuonyeuwa rites are associated with the community gods (demons). It is imperative that those Awka Christians should not be part of these rites. The church should open marriage counselling institute with skilled priests as teachers to counsel the singles and couples on the Christian marriage ethics. The Awka Christians should not be part of Imoka festival for whatever reason, because they cannot worship God of Jesus Christ and at the same time their community deity. They have to make a choice as written in Joshua 24:1-28 especially verses $14-15$ which said,

So fear the Lord and serve him whole-heartedly. Put away forever the idols your ancestors worshipped when they lived beyond the Euphrates River and in Egypt. Serve the Lord alone. But if you refuse to serve the Lord, then choose today whom you will serve.

To worship God is, however, a matter of choice and not by compulsion. On the other hand, since ikponyeajan'ili (dust-to-dust rite) by a widow is partly the conundrum of gender discrimination or taboo by the Awka people; and partly the cause of factions among the Awka people, therefore the Church should adopt optional approach in dealing with this issue. Pastoral care and counselling in this case is capable of diffusing tension, violence and other forms of religious conflict tendencies. Ikponyeajan'ili (dust-to-dust rite) by widow has engendered mass exist of the proselytes from Catholic Church to the new religious movements that will tolerate them.

In respect of Imoka festival, there should be reformation by the Church and the natives to make it entertaining, informative and educative. Religious education is also suggested, because of its transforming, empowerment, changing, self-discovering, and capable of killing ignorance associated with dark ages or ancient rites.

Mobilization promotes mental orientation, re-ordering moral and religious behaviour; organize seminars, symposia and public lectures. Effective mobilization will encourage active involvement in social, religious and political policies that will promote unity among 
the Awka indigenes and the church. It is now a matter of common knowledge that our culture is battling desperately against foreigninspired cultural cancer such as corruption, human trafficking, bureaucracy and nepotism and the injustice of confidential report, denial of merited official promotions, authoritarianism and arrogance in power, academic dishonesty, mammonism or the worship of money, denominationalism, religious discrimination and fanaticism, leadership crisis, and lack of compassion for the common man. All the above mentioned symptoms of cultural malaise and disorder are foreign to the fundamental values of our culture. The fact remains that unless an organized religion or church is firmly planted in the cultural soil of the people, it is on the quick sand of instability and danger of losing its credibility in, and hold on, that culture.

Things are changing rapidly around the church and she has to take account of the phenomena of change. Let her remember history. There was a church in North Africa. That church was the mother of those great makers of church history-Augustine, Tertullian, Cyril, Athanasius, and Berbers, to name a few. She is no longer in existence today; she perished long ago. And why? It was basically because she remained a foreigner and never belonged in the environment in which she lived. Was that not partly the reason for the death also of the church founded in Nigeria in fifteenth century through the activities of the Portuguese and Spanish missionaries? In such typical instances which church history amply supplies, the church in Awka has her lesson, if she will only learn it. The church must respect, preserve, and dedicate to the glory of God anything that is of value in the culture and institutions of the people. 
Nmah: Christianity and Awka Socio-Religio-Cultural Identity Crisis...

\section{References}

Afigbo, A. (1981). Ropes of Sand: Studies in Igbo history and culture. London:

Oxford University.

Barclay, W. (1982).The daily study Bible: the letters to the Corinthians.

Edinburgh: The Saint Andrew

Press.

Evwierhoma, M. (2007).Nigeria: A flourishing culture in diversity. Abuja: NICO.

Fichter, J. H. (1957). Sociology. Chicago: Chicago University Press. Hick, J. and Knitter, P. F. (1987).The myth of Christian uniqueness: toward a pluralistic theology of religions (Eds.). London: SCM.

Idowu, B. (1973). Towards an indigenous church. Ibadan: Oluseyi. Ikenga-Metuh, E. (Ed.) (1996). African inculturation theology: Africanizing Christianity. Onitsha: Imico Books.

Iwe, N. S. S. (nd). Christianity \& Culture in Africa. Onitsha: Varsity Industrial Press.

Iwe, N. S. S. (1991). Socio-ethical issues in Nigeria. Obosi: Pacific. Kanu, R. C. (1996). Christianity and culture at Cross-roads: A case study of Awka town. Unpublished project, Department of Religion and Theology, Paul University-Awka. Knitter, F. (1985). No other name? : A critical survey of Christian attitudes toward the world religions. New

York: Mary Knoll.

Krass, A. C. (1982). Applied theology 1: Go ... and make disciples (TEF Study Guide 9). London: SPCK.

Mussen, P. H. (1963). The Psychological development of the child. New Jersey:

Macquarrie, J. (Ed.). (1981). A dictionary of Christian ethics. London: SCM.

Nmah, P. E. (2008). Religion and society in Africa. Enugu: Rabboni.

Nmah, P. E. (2009). "Conflicts between two religious cultures: achieving reconciliation" in Journal of Religion and Human Relations, vol. 1 No. 2, 24-40.

Nmah, P. E. (2011). "Spiritual dimension in land identity crisis in Igboland of Nigeria: an ethical reflection" in Ujah: Unizik Journal of Arts and Humanities-indexed African Journals online: http:/dx.doi.org/10.4314/ujah.vizi2.6,136-151. 
Nmah, P. E. (2012). Basic and applied Christian ethics: an African perspective. Onithsa Gucks Systems INT'L.

Nmah, P. E. \&Udezo, B.O.S. (2015). "Incarnational theology in Africa: A Christo-centric perspective” in Mediterranean Journal of Social Sciences, Vol. 6, No. 3, May, 263-268.

Obafemi, O. (2011). Nigerian culture: An overview. In O. Obafemi\& B. Ayakoroma (Eds.), Perspectives on cultural administration in Nigeria. Ibadan: Kraft Books.

Obiajulu, A.O. (2003). Culture conflict in human societies.In A.O. Obiajulu (Ed.) Readings in Humanities. Enugu: John Jacob's Classic Publishers, 10-22.

Ofodile, C. (2013). Historical facts on African religion and Awka traditions. Retrieved March 28, 2013 from http:www.google.com.

Okafor, A. (1992). The Awka people. Onitsha: Chudo.

Okeke, M. N. (2015). Burial rites in the Catholic Diocese of Awka: A study in socio-religious conflict. Unpublished dissertation, Department of Religion and Human Relations, NnamdiAzikiwe University-Awka.

Rokeach, M. (1973).The nature of human values. New York: The Free Press.

Scupin, R. (2000). The anthropological perspective on religion. In R. Scupin (Ed.), Religion and culture: An anthropological focus. New Jersey: Prentice-Hall, Inc, 1-15.

Shaver, J. \& Strong, W. 1976).Facing values decisions: rationale building for teachers. Calif: Wadsworth.

Taylor, E. B. (1871). Primitive Culture. London: -.

Udoye, I. \&Ofoegbu, C. (2011).A morphological analysis of Awka personal names. Journal of Arts and Contemporary Society, $3,85-89$. 